\title{
Transcendence, immanence and religious experience in a post-transcendence era
}

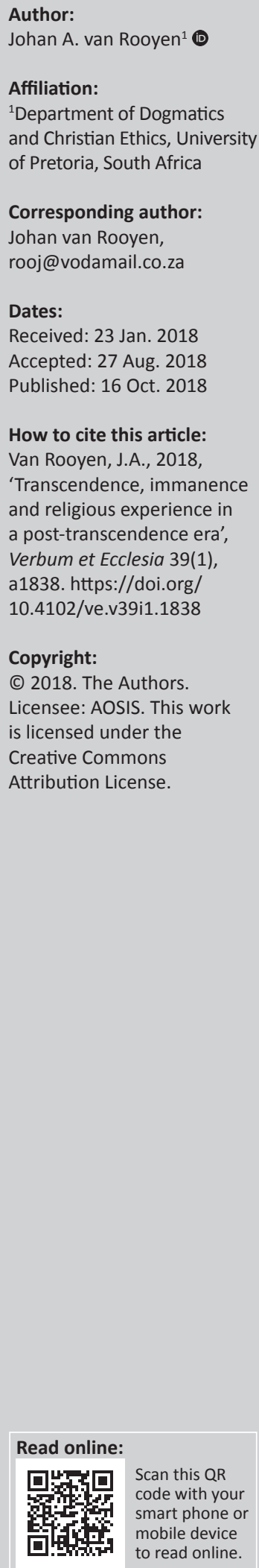

This article presents and critically discusses transcendence and immanence as discussed by the contemporary South African theologians Cornel W. du Toit, Klaus Nürnberger and Anné H. Verhoef. Two questions categorise and guide the discussion: (1) If Western thought has already moved to a notion of post-transcendence, why does transcendence still resonate in our religious academic context? Why is transcendence and immanence still discussed, interpreted and explained in various interdisciplinary disciplines (theology, philosophy and literature) - especially as an expression of the divine? (2) Why is it important in terms of religious experience (in a post-transcendence era) to emphasise that we as Homo sapiens are genetically 'coded' for transcendence? Are we by nature 'biologically wired' to be self-transcended; to be transcended orientated beings? What does this mean in terms of religious experience and our need to continuously shift (displace) the borders of transcendence and immanence? This article develops an answer to these questions that encourages and motivates a better understanding of the shifting borders of transcendence and immanence and the necessity thereof in terms of interpreting religious experience. It will also be pointed out that such an understanding should be informed by an interdisciplinary understanding of transcendence and immanence, which also elucidate the reality that transcendence and immanence are Homo sapiens, experience of the divine in a post-transcendence area.

Intradisciplinary and/or interdisciplinary implications: Why is transcendence and immanence still discussed, interpreted and explained in various interdisciplinary disciplines (theology, philosophy and literature) - especially as an expression of the divine? And why is it important in terms of religious experience (in a post-transcendence era) to emphasise that we as Homo sapiens are genetically 'coded' to transcendence? Are we by nature 'biologically wired' to be self-transcended and to be transcended orientated beings? These questions have implications for all disciplines - such as theology, religious studies, philosophy, art, literature, psychology and natural sciences - which focus on the question of transcendence.

\section{Introduction}

The entire contemporary discourse on transcendence and immanence is too broad a scope to focus on in this article. The article's scope is therefore limited to a selection of published works by three South African theologians: Du Toit (2007, 2010a, 2010b) and Nürnberger (2011, 2016), who have much in common in their understanding of transcendence and immanence, and Verhoef $(2013,2016,2017)$, whose work adds a different or contrasting note to this conversation. Verhoef's views on transcendence and immanence furthermore help to illuminate the posttranscendent context in which this article's questions are raised. What stands out in Du Toit and Nürnberger's views are that both regard experiential realism ${ }^{1}$ to be the best way of understanding Homo sapiens ${ }^{2}$ as informed by the modern world's assumptions. Verhoef, on the other hand, writes from a more philosophical context in his understanding of transcendence and immanence. He outlines the challenges within a post-transcendental age for a reinterpretation (or reconceptualisation) of transcendence (and immanence), especially for theology and philosophy of religion. That being said, the similarities between these three scholar's views of transcendence and immanence are painstakingly close to one another, as will be explained below.

1.Experiential realism focuses on actual potential experiences, on the genetically acquired make-up of the organism, or on the organism's interactions in the social and physical environment, and in that sense, it is experiential.

2.Please take cognisance that the author uses the terms Homo sapient(s) or Human(s) interchangeably as the continuation with the one or the other sometimes leads to misinterpretation. However, for the purpose of this article, both means the same and must be epistemologically understood as exactly the same. 
The five headings in this article summarise the main thread of the argument. The headings are: (1) the displacement of experiences in space and time with regard to transcendence in theology, philosophy and the natural science, (2) posttranscendence, (3) transcendence versus immanence, (4) theological transcendence and philosophy and (5) conclusion. The article concludes with an appropriation of transcendence and immanence within the shifts or displacements of Homo sapiens' consciousness of interpreted religious experience.

There are several reasons why I have chosen the abovementioned three South African theologians' discussion of transcendence and immanence. The first is that they work from within the South African context, but also within the broader post-metaphysical context, with the persistent reappearance of transcendence, especially in and through religious experience. They attempt in diverse ways to deal 'better' with our religious experiences as transcendence within our post-metaphysical age. Their work, secondly, provides some alternative understandings of transcendence in relation to the 'orchestrated secularised voice' (universally and in South Africa), which proclaims that religion, and for that matter, God, is dead - 'Gott ist tot' (Nietzsche). $\mathrm{Du}$ Toit's notion of Homo sapiens' biological or genetic 'wiredness' or 'codedness' for transcendence is especially astute for understanding religious experiences in this regard (Du Toit 2010a).

To translate the above into the context of this article's aim: In the dense and robust contemporary theology or religion science discourses, the place or notion of transcendence and immanence are questioned. The situatedness of transcendence (or at least our experience thereof) is posited within human cognition - within the mind with its respective ability ('Fähigkeit'). The following statement of Verhoef, regarding Malabou's plasticity (the dynamic nature of the brain) as the 'situatedness of transcendence' can function as the 'other side of the same coin' of this article's aim and scope. Verhoef (2016a) remarks:

With Malabou's focus on plasticity she moves to the functioning of a biological system and thereby enters the world of untainted materiality. In doing so, Malabou rejects a messianic, unknown and unknowable, understanding of time and proposes a dialectic understanding of time. This dialectic develops because the plasticity of the transcendental (Kant) is, on the one hand, historical, in that, the truth is nothing outside the genealogical composition thereof, and, on the other hand, biological, in as far as we must keep the natural character of the creative power of reason in mind. In this dialectic position, humans are themselves responsible for the forming of their rational products, convictions and value, like transcendence and time, while knowing that all of this is deconstructable. Therefore, transcendence is just another concept, conviction, or value, like time, that is part of the plasticity of the human brain and thus is malleable, transformable and deconstructable. Transcendence is possible only as radical immanence, which is radically situated within the biological, and in the philosophical new materialism. There is no outside, no transcendence, breaches, or holes, as Malabou postulates. (p. 3)
For example, under the heading, Embodied religion's radicalisation of immanence, Verhoef (2013) mentioned that in coherence with Du Toit:

... we live in the era of what I would call the bodily turn, in which new insights help us to understand the bodily, biological roots of mind, language and cognition in new ways. This has a ripple effect, triggering reflection on spirituality in a postsecularisation, techno-scientific context, which has implications for our present-day understanding of God. (p. 187)

One of the implications, in my view, is that many Christians (especially in the South African context) whom I am most familiar with do not believe in miracles anymore. There are, however, so many 'supernatural happenings' today (within our daily experienced reality and existence) that one needs to rethink the notion of miracles. These 'supernatural happenings' (in its experienced reality) elude humans' understanding and are therefore described as the impossible (unknown and unknowable).

Within a post-modern context (where theologians make ongoing footnotes to align 'supernatural happenings' with modernistic convictions), there is a growing awareness that we live in a world of interpretation. One's thoughts (or interests) cannot therefore be exclusively categorised by the sciences, philosophy or religions (theology). In abroaderinterdisciplinary sense, there is an acknowledgment that organisms (like human beings) managed to understand and use their experiences as coded $^{3}$ : evolutionary biological, epistemological as well as ontological. This happened over a prolonged evolutionary time (and space), and this made it possible for species to use such an experience, just for their own benefit. As an example, an innate expectation (intuitive awareness) can be used repeatedly, such as expectations that are based on the process of accumulation of that specific species. This innate expectation as a culminated experience brings me to the first topic: the displacement of transcendence and immanence that exists, in theology, philosophy ${ }^{4}$ and the natural science.

\section{The displacement of experiences in space and time with regard to transcendence in theology, philosophy and the natural science}

The borders of transcendence are understood according to our experienced (interpreted) experiences. Because we

3.Please take note that in the context of this article, the term 'coded' could have been substituted with the term 'wired', for example, Homo sapiens are biologically 'coded' or 'wired' for transcendence.

4.Verhoef (2016) makes an important observation in the context of the questions asked in the beginning of this article, and to the intuitive experience of transcendence. Such experience eludes previous understandings of transcendence. Verhoef remarks:

In philosophy and theology, earlier understanding of transcendence was conceived of in a radical and vertical way, but more recent understandings are marked by a shift in meaning towards horizontal and radical immanence in Continental philosophy of religion. (p. 2)

My question is as follows: is the concept of transcendence not losing the impact and meaning regarding the crossing of borders? Do we not eventually have a contradiction in terms here? These questions escalate in importance when one reviews the recent developments in Continental philosophy of religion. 
live within a changing time and space (world) as a constant reality, the borders of transcendence will always be transcending borders. There are different views of the borders of transcendence. There are cognitive borders (those that transcend our thoughts and reasoning) that exist, most of the time, next to each other in a specific time and space. Moreover, the different views of transcendence's borders can only be used in some independent modus to see which conviction is the dominant one. The borders ${ }^{5}$ of transcendence have to do with epistemology, with subjective understanding and with forces of power in a specific historical time. Religiously viewed, an experience of a transcendent does not constitute a transparent understanding into the 'being' of the transcendent, but rather a transparent perspective of Homo sapiens' own understanding of themselves and their world. ${ }^{6}$ It is therefore a necessity to understand any religious consciousness (as transcendence) as the outcome of the relationship of Homo sapiens towards God. In the natural science, certain developments created new spaces and opened up humans' understanding of the telos-transcendence as workings of God ${ }^{7}$ in a non-interventionist way. Verhoef (2016:1) argues, for example, that transcendence and eschatology cannot be separated, and asks furthermore: why is there this need to reconceptualise transcendence at all? Why did so many interpretations of transcendence develop in our postmetaphysical time? Why is transcendence still important? And, can transcendence be found, and if so, how and where?

At this point of the article, one needs to look more closely at the notion of post-transcendence. I regard post-transcendence important because we as humans must gather our thoughts on transcendence, while we are currently living in a posttranscended time and space (world).

\section{Post-transcendence}

If Western thought is characterised with the notion that it has already moved to post-transcendence (implying that only immanence is left), why would transcendence still resonate

5.Also, take cognisance of the fact that the term 'border' could also have been substituted, in the context of this article, with 'boundary', 'boundaries', 'post(s)' or 'frontier(s)'. However, I am making use of the term 'border' as it better underline the meaning of what I want to explain. At the same time, I would like to state upfront: I speak on behalf of conscious embodied beings on transcendence and immanence. I can only acknowledge the possibility of a definite understanding of what transcendence and immanence means in the realm of a conscious interpreted religious mind. The crucial question in this regard is not if either transcendence or relgious mind. The crucial question in this regard is not if either transcendence or immanence is part of my interpreted thought structure, but rather, how I as functionalities to better the meaning, for the sake of myself, to enhance my understanding of myself, God, and the world I live in.

6.Klaus Nürnberger (2011) remarks to this in a 'warning modus':

Humans are so vulnerable and mortal. We are dependent on a system of knowledge that we belong, what roles is to play in our lives lived and our roles in the bigger picture of things. Transcendence therefore, has to do with those moments where every day human experiences are loaded with the faith and moments where every day human experiences are loaded with the faith and work of God. Therefore, especially the Christian believers cannot afford to try to negate the transcended origin of transcendence. (p. 198)

7.Regarding this specifically being said, at this stage of the article, one must take note of Verhoef's (2016) statement:

Transcendence is first typified as radical transcendence. This is a vertical type of transcendence where the absolute (God) is (1) seen as the totally other, and (2) clearly distinguished from the mundane reality. This type of transcendence becomes problematic if all value of the world is linked merely to the divine, since there is a danger that nihilism (read: life is meaningless) may arise should the possibility of the danger that nihilism (read: life is meaningless) may arise should the possibility of the
transcendent be questioned. In philosophy, this type of questioning is especially transcendent be questioned. In philosophy, this type of question
prevalent in the onto-theological critique of metaphysics. (p. 1) in our religious academic contexts? Why did it become necessary to discuss, reinterpret and explain transcendence and immanence in a more interdisciplinary way - especially if it is an expression of divine transcendence? Why is it furthermore so important, in regard to religious experience in a post-transcendence era, to emphasise that Homo sapiens are genetically 'coded' to be self-transcended, to be these transcended orientated beings, that still want to shift all their borders of existing transcendence or even the borders of their immanence? Is it not given that a Homo sapiens cannot exist without these borders, precisely because transcendence can only be reinterpreted to enable us to make rational as well as interpretive decisions to adapt ourselves to understand transcendence or immanence? This is not only about faith in the existence of God, as a transcendent characteristic (codedness) of Homo sapiens, but also of ourselves.

The radical reinterpretations of transcendence had its origin in the science revolution of the 15th century and it peaked in our modern time in which the notion of metaphysics was negated. The influence of the new cosmology ${ }^{8}$ (unique way of thinking about time and space), new biology and cognitive brain sciences, on philosophy, were eventually changing viewpoints on transcendence. In this post-metaphysical or post-transcendental context, theology tried to maintain its credibility amidst the vast influences of the new technosciences. Besides, post-transcendence does not imply that there is no transcendence to be found, but only implies a new view on how transcendence is reinterpreted. This changing interpretation of transcendence does not only make believe in the existence of God problematic, but also belief in Homo sapiens as self-transcended and transcendent-directed beings. The question now arises: how far did the transcended borders shift as a direct result of the techno-sciences? Without an over-generalisation, the following aspects of the traditional Christian viewpoints are not currently acceptable: belief in miracles that goes against the grain of the laws of nature, belief in an eternal life after death or pain in the hell of fire. Also, belief in sin which typifies the deepest sense of being human, as personal suffering, and ascribing it to evil or as the will of God.

Therefore, does the unknown, especially in the dangerous and threatening modus, characterise transcendence? Especially the unknown that manifests itself through evil becomes the incomprehensible, inconceivable, radical transcendent.

8.Du Toit (2010) explains it as follows:

The new cosmology debate has explored numerous possibilities to accommodate God's actions on earth without jeopardising the integrity of natural laws. The premise is that God voluntarily submits to laws that he himself decreed. The trend known as intelligent design was largely rejected and attempts to find an acceptable work place, a causal joint where God can intervene without violating natural laws whom have not been conspicuously successful either. The openings or frontier posts found in science-theology debates where God can act, in a non-interventionist manner, are at the micro level of quantum uncertainty, complexity systems, the role of chance in evolution, autopoietic, self-creating, cell systems in biology, and the notion of emergence. Of course, the critical question here is: if a plausible space is found where God can act non-interventionistically, why doesn't he use it? space is found where God can act non-interventionistically, why doesn't he use it? Why does the reality of suffering and evil still prevail? It also raises the question of human freedom and determinism. If God exercises his will at quantum level, where do our will and freedom feature? This approach moreover rules out a persona encounter with God. We cannot genuinely communicate with a god who operates at quantum level. This discourse must be regarded as an attempt to smuggle in modern-day proofs of God's existence, which inevitably entails a new noumena metaphysics, an omnipotent, omnipresent God controlling everything. (p. 16) 
When the inconceivable is explained, it becomes transparent and it loses its threat and intimidation. Even if we do not understand an unknown sickness, it loses its menace when we give it a name or explain it medically. Nevertheless, for radical evil, no name or explanation is to be found, and we cannot guess about it. Furthermore, it is not consistent to associate evil with social or psychological theories. ${ }^{9}$ It is best to accommodate and understand the inconceivability of transcendence in a negative experience, rather than a positive one. Why? Because faith in a god or the supernatural is coming from Homo sapiens (mind or brain). The Homo sapient immanent aspect of faith can be understood from the mechanisms of the Homo sapient consciousness, thoughts (philosophy), language (metaphors), physicality (biology, brain sciences) and culture (sociology, psychology, etc.). To negate faith and faith-experience from these dimensions are impossible, as it does not make sense without it. The Homo sapient consciousness is the most important aspect of this Homo sapient immanence of faith, and therefore it can incorporate and discriminate through all its modes of experiences (the things that happen to them or us in reality).

Transcendence has to do with all Homo sapiens' experiences of dependency, especially on the level of faith. On anthropological level, it has to do with all levels of incompleteness and openness. On an epistemological level, it has to do with our understanding of our reality of Homo sapiens as subjects. Du Toit (2010b:97) puts it like this: 'In a sense, epistemological inquiry into knowledge, the role of transcendental reflection in knowledge, the relation of subject to object and the like remain formal and abstract'. On the level of faith, Homo sapiens' dependence on gods and forces around us are substituted with forces and influences around us. Because of this substitution, theologians, such as Anselm, Archbishop of Canterbury (11th century), the American theologian Paul Tillich (20th century) and the Dutch philosopher and theologian Wessel Stoker (21st century), to name a few, insist that faith must be understood as rational. Each of these individuals tried to do just that in their own unique way. ${ }^{10}$ Nevertheless, what is this transcendence then that resonates so freely with and sometimes against immanence?

\section{Transcendence versus immanence}

Traditionally, transcendence and immanence are opposing each other as two opposite poles. This is misleading, as both are not easy to understand, as they are diverse, plural

\footnotetext{
9. Nürnberger (2011.199) explains it in the following modus: "Humans who do not experience themselves, dependent and accountable, live in a fool's paradise. experience themselves, dependent and accountable, live in a fool's paradise.
Human consciousness cannot operate without structure and orientation'. Thus, Human consciousness cannot operate without structure and orientation'. Thus,
when Homo sapiens try to live without any suppositions and need, they are when Homo sapiens try to live without any suppositions and need, they are
engulfed with an overwhelming and surprising aspect of life. They may end up in dead-end streets, where they assume unrestricted autonomy. They then deceive themselves. Homo sapiens are not self-constituting, self-maintaining, self-defining and self-accountable and they cannot be.

10.Anselm of Canterbury did not just believe and accept what his religion taught him but he tried to explain in rational terms that God indeed exists, and that rationality
does not exist separately from faith. He believed that the Christian religion was the basic fundament for Homo sapient existence. Paul Tillich, on the other hand, also basic fundament for Homo sapient existence. Paul Tillich, on the other hand, also
tried to do the same. He rejected the language of the church and tried to communicate rationality of faith through another channel, that of being Homo sapient. He admits that there was an inexplicable difference between the world of God and the world of Homo sapiens, and therefore he propagates that to taste the world is to also experience God. He talks about the profoundness of righteousness, love, aesthetics and the seeking of the truth.
}

and dualistic. Immanence is so loaded with transcendence that one can easily suppose that it is precisely the experience of human's earthly existence that leads to metaphysical transcendentalism (metaphysical idealism). Du Toit (2007:284) elaborates: 'The tradition of empiricism with its focus on physically observable reality views the metaphysical or trans-physical as transcendentalism'. Transcendence has to do with the experience and construction of borders, even if these borders have to do with empirical reality or thought borders of structural brain borders. Humans are bordered beings, as they are biologically structured as coded beings: they bring into existence borders through their consciousness of time and space, sensory sense and physical limitations, the unknown (radical evil), mortality and frequent changing world and it is therefore that humans' vulnerability is one of intimacy, of the same relationship, which is immanent and transcendent.

Notwithstanding this, Homo sapiens know where the location of their existing borders is, and where it can be crossed. Theoretically, there are some borders that can never be crossed and unfortunately Homo sapiens must accept this. By not doing so, their thinking can be regarded as highly speculative of what can be found 'on the other side'. In this context, Du Toit (2010a:11) refers to the Kantian Ding an sich (a thing that is in itself not mediated through perception by the senses or conceptualisation and therefore unknowable). Du Toit (2010b) wrote:

The nature of the human mind and its concomitant thought processes which entail concepts like infinity, unknowability of the Ding an sich cannot but impose a perennial character on the sciences, from philosophy, epistemology and psychology to physics. (p. 87)

As an example of a physical border, we can think of borders that are set by nature such as mountain ranges, the ocean, time and space that include the current unsearchableness of outer space (and time) as a physical border. Humans must wait for the day of tomorrow and the distant past still seems a mystery. A border to our measuring instruments prohibits us to look further than the current borders. Our human consciousness also set borders that are not only physical borders but also are complex, abstract and vague in and from our existential experience. It is interchangeable with our borders in our consciousness like the difference between our thought patterns and our embodiment, the duality of our consciousness and self-consciousness and the differential within the consciousness as when we are against the inner self, especially when we are in conversation with ourselves.

There is also the border in Homo sapiens' inner world as well as the external world: the border between myself and the unpredictable other being as an object outside of myself, the border of my eschatology or death and God as the border of the totally transcended. In this way, the openness of 'to be' should be regarded as a border. There are also borders that are instituted through the law and authorities such as the 
church and justice that incorporate theoretical and moral implications. Subjacent to all borders are those that have its relevance in time and space, but also with knowledge, beliefs, consciousness and experience.

To take the border metaphor even further, the term 'border(s)' can be described as crossed openings or exits (like border posts). In a scientific context, the telescope of Galileo can be regarded as an opening that creates a new framework of theory and interpretation. Most of the time borders exist where mountain ranges and rivers allow it, so that these borders can be crossed. These 'openings' lend itself to border traffic and with that, inevitable border posts. Certain traffic through border posts is not allowed in certain conditions and must be adhered too. In a religious sense, these openings are regarded as revelation borders which act as in-between spaces which join two opposite forces. It is described as revelation borders, meeting borders or a joint or hinge borders. These are always referred to in subjective modus: God appears through a vision, dream (Jacob's ladder); a Damascus experience (Paul). Homo sapiens characterise these hinge borders with extraordinary meaning and connotation and then explain these hinge borders with images that are fitting and relevant. As per example: holy ground, born-again, profoundness that took place (mystique of Buddhism), a being that appears in a moment of illumination, the spoken word that took place (Ebeling) so that ordinary language becomes a life-changing experience.

From an experiential realism context, the hinge from Homo sapient side is the meeting place with the transcended or supernatural. This must be understood and elucidated; otherwise, no meaning can be attached to it. The hinge from God's side is a place of incarnation, announcement and notification as the divine, as, for example, with the burning bush, or historical event (the birth of Jesus), the word Logos and the Spirit. However, in an incarnated form, the divine must also be different, radically different; otherwise, it remains a common Homo sapient endeavour. For example, the earthly Jesus was radically different as he transcended the world as he performed common Homo sapient deeds in a total unique and unusual way. As Nürnberger (2016) so eloquently puts it:

While it is impossible to imagine God, the transcended Source and Destiny of reality, we can indeed imagine Jesus, the Christ, in whom the benevolent intentionality of God manifested itself. (p. 5)

However, Nürnberger (2016:54) warns us: 'This is not meant to discount the importance of penetrating other cultures, religions, and worldviews with the Christian witness'.

The point is simply that modernity became the dominant world view in our times and that we must become, as Nürnberger puts it, ' ...a modernist to modernists if we want to reach modernists without message'. We can do this because Christ was a human in an individual and historical ability whose life followed on us a magnitude of consequences in our world full of immanent and transcended borders. A historical human, indeed an immanent border, onto which our images are transcended. Nürnberger (2016) expresses these dimensions of the concept of reaching modernists without message (of theology) in two basic propositions:

When theology assumes that reality is open to a transcended Source and Destiny rather than closed in upon itself, thus all there is, it picks up an intuition, which emerged and evolved in human history over countless generations. In this case, the content of this intuition cannot be substantiated because something deemed transcendent is not accessible to human observation.

However, one can indeed spell out the immanent causes of such an intuition namely, the universal sense of derivation, dependency, vulnerability, mortality and accountability, all of which imply a higher Source, Destiny or Authority. One can also spell out the consequences of alternative intuitions or notions of the transcended and ask which would facilitate the movement of humanity in the direction of a vision of comprehensive optimal well-being best. (p. 54)

This can be seen when Jesus (as God in Trinitarian fashion) transgresses and violates Homo sapient laws when he accommodates the earthly ostracised, in offering them forgiveness, empathy and love in situations, while it was in his time uncommon to do so. Verhoef (2017) refers in this regard to the Spirit in kenotic form:

This world is important, and not an outside world. God is within this world, incarnated in Jesus. He emptied Himself as Spirit in kenotic form, and therefore is he found within the world itself, within humanity as the body of Christ. Plain immanent doings can accommodate the transcended. It therefore means that common human thoughts and doings can accommodate the transcended. The divinity appears in human love, hope, faith, empathy, forgiveness, eschatological forthcoming, interaction with thy neighbour. (p. 4)

Transcendence, however, does not fall by the wayside when it is regarded as normal Homo sapient behaviour, because it inclines to propagate other dimensions. Du Toit (2010a) points out:

No form of transcendence that can be thought of can be taken away from human endeavour, but in a way that God traditionally reveal and meet humans as Himself, seems to be a problem for the current contemporary human. As an example, miracles that exonerate the law of nature, as we know it today; metaphysical language and deconstruction that does not make sense anymore: and it then begs humans to ask for a re-shifting of these established borders. (p. 2)

Under the heading 'Reductionist Nature of Immanence', Verhoef (2016), in his sublime article 'Transimmanence and the im/possible relationship between eschatology and transcendence', emphasises the 'setting up of borders' when he categorically states:

Critique on immanence as our final and totally closed-off reality is expressed in different interdisciplinary countermovements and voices. In art and post-phenomenology, this critique hinges on an existential longing for or an experiential claim about an ultimate sense of life breaking in from beyond Homo sapient 
relations and history. This ultimate sense of life and the experiences of reality as a subjective force, being, God, the Other fate, lead to the continuous shifting views or frontiers of transcendence in philosophy, theology, art, politics, and literature. In phenomenological terms, transcendence is, for example, described as that which breaks in upon us through saturated phenomena - phenomena that exceed our intuition and our conceptual control. Schrijver's says, for example, that this world is not mere world, it is not merely passing, because it is in and through love that one encounters, embraces, and holds on to a sense that surpasses the endless finitude of things. In theology transcendence resurfaces as the mystical, and in literature it points to that within representation that nonetheless exceeds representation. (p. 5)

With this shifting of Homo sapient meeting borders in mind, I am now going to investigate the origin (from theology's side) of how theology and philosophy have tried to accommodate the transcended nature of God's revelation and transcendental religious experiences of God within the immanent. To do this, I will look closer at the impact that the concept transcendence had on theology and philosophy.

\section{Theological transcendence and philosophy}

In the Old Testament, we experience Homo sapiens as some confined bordered beings as it appears in the stories of creation. God creates out of nothing, creatio ex nihilo, and when creation finished, it happens through the establishment of borders and can be distinguished in the following examples: light from dark, mainland from sea, water from atmosphere, water on earth, man and woman, and the week and the Sabbath. The second story of creation leads us to differentiate between the borders as Homo sapient matter and Homo sapient Geist (Spirit), and in the story of the paradise, borders of life and death are revealed. These physical borders involve our daily life in such a profound way that it becomes our faith life: the time border, Sabbath and festive times as holy times, space borders as holy places.

There is also a border where humans meet God, for example the temple and after exile, the border shifted to the Word. In the New Testament, the Shekhinah, a term that means house or place of a living God, refers especially to the temple of Jerusalem where he is present. Therefore, miracles became part of the world view of the ancient time and were not regarded as a violation of the laws of nature, as we know it today. Believing in miracles then (in that time) did not have the same impact on Homo sapiens as today. It was only signs that projected God's love towards his faithful people. The Old Testament is full of examples where God used every day life experiences wherein he gave new meaning to it. God is the God of promise that gave this promise as a covenant to his people of faith. God is God of history that goes with us through life. Accordingly, God stays transcendent and no symbols can be contracted, although God exists in our lives.
Theologically understood, God is the origin of all transcendence. Within the framework of the Christian faith, God's revelation is found in a border opening, namely the birth of Christ. Christ is the 'border opening' to God, so that God can live among us. Christ self is now the opening to God as being the 'Way or Passage' (the Gospel of John). Later, miracles came forth as openings to experience God through prayer and the working of the Holy Spirit. It is important here to remember that the 'border traffic' is always two-way traffic.

Du Toit (2010b:83) refers to another 'border opening', namely God's meeting with the human race in the garden of Eden: 'The Old Testament story of the Fall presupposes a paradisiacal state, but who really knows what that was'? The notion of paradisiacal bliss, like the notion of infinity, can only be understood in terms of Homo sapient experience of need and desire. 'Poros's abundance is as infinite as Penia's want'. Perfect harmony in its infinitude is unknowable. Plato connects Eros with the idea of creation and creation entails a dual infinitude: all things emerge from nothingness and are born towards the infinite. The same applies to any science that grows from the 'nihil' of genesis. This mixture of finitude and infinity, of fulfilment and unfulfillment characterises the development of thought from 'mythos' to 'logos'. Logos does not mean unadulterated, unequivocal truth. It is never free of myth.

Because of this, mystical elements resort to metaphors, models and analogy, all strategies indicating that we do not fully know. Nürnberger (2016:5) refers to the metaphor when he describes that: 'Christians attach a definite meaning to ultimate Source, namely creative power, which is an anthropomorphic metaphor for whatever may ultimately drive the cosmic process'. 'We cannot comprehend fully what transcendence is, so we cannot study God as such, and we may not indulge in speculation to make up our own ignorance' (Nürnberger 2016:6).$^{11}$ These considerations must guide us when we speak about God. God is not real in the sense that things and events in this world are real. 'Therefore, God does not exist the way dogs, whirlwinds, or skyscrapers exist' (Nürnberger 2016:54).

As seen from 'below', humans must try to meet and know the unknown. An exception for this is:
... that it is God that knows and meet humans. From another border-view, the question begs: How does God work in human world? From human side, God can only be understood through mediation of a filter. In the history of religions, the most prominent of these filters were the language-filters that crystallised into the form of metaphors, analogy and symbols as explained-filters in the form of Gods exhibits and apophatic theology. (Du Toit 2010a:7)

As experience filters in the form of rituals and sacraments, as theology disciplines of mysticism and dogmatic filters 11.Nürnberger (2016):
So, theology is not, as the name seems to suggest, a study of God. Theology can
only critically analyse existing notions of God and propose a notion that is
appropriate. That is the realm in which theology can meaningfully operate. (p. 6) 
whereby God is approached through faith, through perhaps Jesus or Mary. These filters are always inevitably characterised by dualism, because godlikeness and humanity are always the opposite of one another. The human side of the hinge projects itself onto the godlike in a process that can only be seen and experienced from one side (earth).

It is also implicated that all true knowledge starts with the knowledge about God. However, all God knowledge is nothing else than new knowledge about Homo sapiens. God does not reveal the unknown, but he lets light shine on it: 'Apophatic and negative theology can do nothing more than to give illuminative perspective on human self-understanding' (Du Toit 2010a:7). Homo sapiens' self-understanding can only be transparent against a world view as insightful, as well as raises questions in a certain time in space where and when Homo sapiens live. Du Toit (2010b) puts it like this:

People have become transparent to each other and no longer relate. The world around us has become explicable and we are left disillusioned in a disenchanted environment. The postmodern mind mourns the loss of mystery, the challenge of the unknown, the desirable and enticing, and the loss of an enchanted world. When we speak of the death of God, the end of metaphysics, the end of subjectivity and the technological transformation of nature, we are actually speaking of a loss of transcendent experience. (p. 77)

Because of this, the meeting and, understanding-borders must shift. When belief-systems become fossilised because of a worldview that once made sense, which is now out-of-date, the meeting-space between transcendence and immanence have to be displaced (Du Toit 2010a:7-8).

This is what is happening in our time. ${ }^{12}$ Today we interpret our transcended structures differently from Bible times. For this (not all the time), we must thank the natural sciences and the re-discovery of Homo sapiens godlikeness, which explains not only the micro but also the macro cosmos, as well as immortal conscious bearer of the infinite. The evolutionary origin of the Homo sapient moral sense indeed tells us nothing about how we get to construct moral decisions, codes and laws. That, however, does not mean that we cannot give a philosophical account of how we arrive at these informed judgements, codes and laws, without having to fall back on supranaturalist or sociobiological 'rules' for moral behaviour. These informed judgements, codes and laws are not metaphysical Homo sapient transcendence but an immanent earthly transcendence that happens to have an events character. Religions that are solely based on metaphysical godlike characteristics are hollow.

What do we mean with theological terms such as godlike, omnipresence, omniscient (all knowing), eternity (infinity) and omnipotence (almighty)? These characteristics unfold outside any scope of Homo sapient understanding and must be avoided. It had the repercussion that all forms of attempts

12. Here, I agree with Du Toit (2010:8) where he deliberates and points to the fact that the thought of border shifting is not to be confused with the Bultmannian non-mythological process (a process where any mythological proposals in the non-mythological process (a process where any mythological proposals in the
New Testament, as well as in the mythological eschatology, should not be regarded New Testament, as well as in the
as existential reinterpretations). to accommodate metaphysical essentiality were rejected by philosophy. There are many examples of these interchangeable views from the side of a theology filter. The onus falls on a Homo sapient incarnated God; the kenosis Jesus, a suffering God that is, historically, on the way with us, which also includes the history process of nature. Besides, Jesus is not only the face of God, but also the face of Homo sapiens, whatever being Homo sapient means in the 'face' of atonement or reconciliation. Jesus left Homo sapiens with a special kind of transcendence, through the way he opened eschatology, which is an eschatology of hope. In this way, humanity obtained forgiveness and prayer of a transcended character. That is why Verhoef (2016) states:

Although we live in a post-metaphysical age, there is a renewed interest in transcendence, especially at the intersection of philosophy, religion, and theology. There are several reasons for this: among others, the important link that the future, eschatology, has with the unknown or that which lies beyond transcendence. (p. 1)

In the beginning, I also alluded to the point that certain considerations on transcendence and immanence must guide us when we speak about God. From an experiential realism point of view (Du Toit and Nürnberger), with which I concur, God cannot be studied. We cannot reach God through metaphysical speculations. What happens is that in a transcended sort of way, notions of God pop-up in our consciousness, especially when we are confronted with the challenge and the offer of a new, authentic way of being Homo sapient in fellowship with God. As Nürnberger (2016) once again puts it peculiarly:

Therefore, we cannot speak about God as we speak about a horserace or a piano; we can only speak of God as the foundation of a new and authentic life. (p. 54)

However, there is a factuality that fortunately resonates in this matter: a transcended character that may never be guaranteed, because if it does, it can no longer be transcendence. As in the time of the ancient Greeks, philosophy played a significant role in putting up borders, between gods and Homo sapiens, between Homo sapiens and reality, between reality and the unreal and between good and bad. The influence of Plato, Neo-Platonism and the Gnostic on Christianity and the earlier church fathers is well documented. Philosophy led the science revolution and brought with it the emergence of modernism, and in our time, post-modernism. Although the focus point is on Homo sapiens as a known subject on knowledge, as well as the metaphysical reality, the thoughts thereof will most certainly influence theology. This certainly makes sense because without God, without transcendence, nothing is not allowed for the common reason. Nothing is good or bad, and nothing has any righteousness. Everything becomes arbitrary when it is Homo sapiens' own.

\section{Conclusion}

Two questions guided this article's focus: (1) If Western thought has already moved to a notion of post-transcendence, why does transcendence still resonate in our religious 
academic context? Why is transcendence and immanence still discussed, interpreted and explained in various interdisciplinary disciplines (theology, philosophy and literature) - especially as an expression of the divine? (2) Why is it important in terms of religious experience (in a post-transcendence era) to emphasise that we as Homo sapiens are genetically 'coded' to transcendence? Are we by nature 'biologically wired' to be self-transcended; to be transcended orientated beings? What does this mean in terms of religious experience and our need to continuously shift (displace) the borders of transcendence and immanence?

Regarding the first, I have shown that so many things 'supernatural happenings' - elude humans' understanding in their experienced reality and that we typify these experiences as the impossible. Therefore, to answer my second question, I mentioned that we live in a world where our thoughts are trapped, taken hostage by our interests in such a way that our experiences of transcendence or 'supernatural happenings' cannot be exclusively categorised by the sciences, philosophy and religions, but need a more interdisciplinary approach. Transcendence then becomes important, especially in the immanent modus thereof.

With regard to the first question, I mentioned that the borders of transcendence have to do with epistemology, subjective views and the forces of power in a specific historical time. Therefore, it is important to take cognisance of the reality (religiously viewed) that a religious experience of God (or the divine) as transcendent is not automatically constituted by a direct relationship from Homo sapient side towards (on a journey to) God. This journey is rather an 'opening of a border' through Christ. With regard to the second question: although Christ opens up the 'border post' to transcendence, we as Homo sapiens should keep on shifting (displacing) our 'borders' of transcendence and immanence. We should not ignore that we are 'biologically wired' for transcendence. There should be an attentiveness to the 'borders' of experiencing the transcendent in the immanent.
As Homo sapiens, we are evolutionarily 'coded' to go beyond everything we do and have. And then, it elucidates the reality that transcendence and immanence are Homo sapiens' experience of the divine in a post-transcendence area.

\section{Acknowledgements}

The author would like to thank Prof. D.P. Veldsman (University of Pretoria), Prof. C.W. du Toit (University of South Africa) and Prof. A.H. Verhoef (North-West University) for their support.

\section{Competing interests}

The author declares that he has no financial or personal relationships that may have inappropriately influenced him in writing this article.

\section{References}

Du Toit, C.W., 2007, Viewed from the shoulders of God: Themes in science and religion, University of South Africa, Pretoria.

Du Toit, C.W., 2010a, 'Shifting frontiers of transcendence in theology, philosophy and science', in C.W. du Toit (ed.), Homo transcendentalis? Transcendence in science and religion: Interdisciplinary perspectives, pp. 1-22, University of South Africa, and religion:
Pretoria.

Du Toit, C.W., 2010b, 'Self-transcendence and Eros: The human condition between desire and the infinite', in C.W. du Toit (ed.), Homo transcendentalis? Transcendence in science and religion: Interdisciplinary perspectives, pp. 77-102, Transcendence in science and religion:l
University of South Africa, Pretoria.

Nürnberger, K., 2011, Regaining sanity for the earth. Why science needs best faith to be responsible. Why faith needs best science to be credible, Cluster Publications, South Africa.

Nürnberger, K., 2016, Faith in Christ today. Invitation to systematic theology Vol II (Involved in God's project), Cluster Publications, Pietermaritzburg.

Verhoef, A.H., 2013, 'Embodied religions' radicalization of immanence and the consequent question of transcendence', Acta Academia 45(4), 173-194, ISSN 0587-2405, UFS, Bloemfontein, viewed 17 June 2018, from http://www.ufs.ac. za/ActaAcademia

Verhoef, A.H., 2016a, 'The end of transcendence in continental philosophy of religion?', viewed 05 October 2017, from www.litnet.co.za/end-transcendencecontinental-philosophy-religion

Verhoef, A.H., 2016b, 'Transimmanence and the im/possible relationship between eschatology and transcendence', Religions 7, 135. https://doi.org/10.3390/rel 7110135

Verhoef, A.H., 2017, 'Encountering transcendence: Žižek, liberation theology and African thought in dialogue', Religions 8, 271. https://doi:10.3390/rel8120271 